\title{
MENINGKATKAN KEMAMPUAN MENULIS NOTASI BALOK MELALUI METODE SOLFEGIO PADA SISWA KELAS VIII-A DI SMP NEGERI 3 KEDIRI
}

\author{
Yayuk Siti Rahayu ${ }^{1}$, Ninik Harini ${ }^{2}$ \\ ${ }^{1}$ SMP Negeri 3 Kediri, ${ }^{2}$ Universitas Negeri Malang \\ E-mail: yysitirahayu@gmail.com
}

\begin{abstract}
The goal of the research is to develop the quality students' learning result in writing partitur / musical scale through solfegio method the students of VIII A at SMPN 3 Kediri. The kind of research is class action research which is done in two cycles. Collecting data is done by using observation techniques, interviewing tests, and documentation. The result of this assessment in cycle is $70,5 \%$ students have got the minimum standard of assessment, while in cycle 2 there are $97,1 \%$ students have achieved the minimum standard of assessment. So, it can be concluded that. The learning result of students in writing musical scales is developed through the solfeggio method.
\end{abstract}

Key words : The enhancement, The ability of writing, solfeggio music.

\begin{abstract}
Abstrak: Tujuan penelitian untuk meningkatkan kualitas hasil belajar menulis notasi balok melalui metode solfegio pada siswa kelas VIII-A di SMP Negeri 3 kediri. Jenis penelitian adalah penelitian tindakan kelas (PTK) yang dilakukan dalam 2 siklus. Pengumpulan data dilakukan dengan teknik observasi, wawancara, tes, dokumentasi. Hasil dari penilaian pada siklus I sebanyak 70,5\% siswa telah mencapai ketuntasan belajar sedangkan pada siklus II sebanyak $97,1 \%$ siswa telah mencapai ketuntasan belajar. Dengan demikian dapat disimpulkan bahwa hasil belajar siswa dalam menulis notasi balok dapat meningkat melalui metode solfegio
\end{abstract}

Kata Kunci: Peningkatan, Kemampuan Menulis, Metode Solfegio

\section{PENDAHULUAN}

Pendidikan merupakan suatu proses untuk mengembangkan semua aspek kepribadian manusia, yang mencakup pengetahuan, keterampilan dan sikapnya. Pendidikan mengemban tugas untuk menghasilkan generasi yang lebih baik, dan manusia yang memiliki kepribadian yang lebih baik.

Permasalahan pendidikan selalu muncul bersamaan dengan perkembangan peningkatan kemampuan siswa, situasi dan kondisi lingkungan yang ada, pengaruh informasi dan kebudayaan serta berkembangnya ilmu pengetahuan dan teknologi. Seiring dengan perkembangan zaman dengan adanya teknologi yang canggih membuka kemungkinan siswa tidak hanya belajar di dalam kelas, akan tetapi bisa juga siswa akan belajar di luar kelas supaya siswa tidak merasa bosan, misalnya siswa diberi tugas untuk mencari data di internet atau di media massa sesuai dengan pelajarannya. Dunia pendidikan dikenal dengan istilah belajar. Tirto Adi (2007, p.33) "Belajar adalah perubahan disposisi atau kemampuan yang dicapai seseorang melalui aktivitas". Perubahan disposisi tersebut bukan diperoleh langsung dari proses pertumbuhan seseorang secara alamiah, banyak hal yang dapat dipelajari sesuai dengan kebutuhan dan materi seperti kegiatan berkesenian. Seperti halnya dalam pendidikan dipecah lagi dengan pendidikan yang berkaitan dengan ilmu sosial, pendidikan ilmu alam dan pendidikan seni.

Belajar seperti demikian, siswa akan

Received on :23/03/2020

Revised on :05/03/2021

Accepted on : 24/03/2021 
lebih leluasa menuangkan gagasan mereka yang dibangun berdasarkan informasi dari berbagai sumber. Suasana atau iklim belajar mengajar harus diciptakan dalam proses pembelajaran, sehingga dapat memotivasi siswa untuk senantiasa belajar dengan baik dan bersemangat. Sebagaimana diketahui bahwa metode mengajar merupakan sarana interaksi guru dengan siswa di dalam kegiatan belajar mengajar.

Berdasarkan hasil observasi dan pengalaman yang telah penulis lakukan di SMPN 3 Kediri, dari sejumlah sepuluh rombongan belajar terdapat satu kelas yang beberapa siswanya belum tuntas dalam pembelajaran Seni Budaya sub Seni Musik. Khususnya pada kelas VIII-A, dari siswa sejumlah 34, hanya $17,7 \%$ siswa yang mencapai KKM. Sebagai upaya untuk meningkatkan hasil belajar, penulis mencoba untuk menerapkan metode lain yang sekiranya bisa meningkatkan hasil belajar siswasiswa kami yaitu mencoba menerapkan model pembelajaran dengan metode solfegio.

Metode solfeggio adalah suatu metode dalam dunia music yang mengacu pada menyanyikan tangga nada, interval, serta latihan-latihan melodi. Latihan tersebut dilakukan dengan syllabus solmization, yaitu menyanyikan nada music dengan menggunakan suku kata (Puspita, 2016, p.154).

Harapannya siswa-siswa kelas VIII-A dapat meningkatkan hasil belajar yang bisa melampaui KKM, yang mana sekolah ini menetapkan KKM sebesar 75 dengan menggunakan Kurikulum Tingkat Satuan Pendidikan atau KTSP. Untuk itu penulis berharap ada peningkatan hasil belajar pada Standar Kompetensi 4. Mengekspresikan diri melalui karya seni musik. Kompetensi Dasar 4.1 Mengaransir secara sederhana lagu etnik Nusantara dalam bentuk ansambel. Terdapat beberapa faktor yang mengakibatkan siswa kurang memahami materi pembelajaran dan masih rendahnya aktivitas siswa dalam proses belajar mengajar. Keaktifan siswa kurang tampak, itu terlihat ketika guru menyampaikan materi, sebagian besar proses pembelajaran siswa kurang berantusias dan kerjasamanya kurang serta kurang aktif. Banyak siswa yang kurang aktif, serta terdapat perilaku-perilaku yang bisa mengganggu proses belajar mengajar. Pada umumnya saat guru mengajar di ruang kelas sebagian waktunya dihabiskan untuk menyampaikan materi pelajaran tanpa memperhatikan kondisi dan kemampuan daya tangkap materi oleh peserta didik. Hasil pengamatan tersebut peneliti mempunyai harapan untuk lebih mengoptimalkan pembelajaran, meningkatkan hasil belajar dan keterampilan siswa dalam menyelesaikan tugas serta melatih karakter siswa.

Salah satu upaya untuk mengatasi masalah yang ada melalui metode solfegio pembelajaran lebih mengutamakan keaktifan siswa dan kerjasama memberi kesempatan siswa untuk mengembangkan potensinya secara maksimal. Metode pembelajaran yang dimaksud adalah metode solfegio.

Dalam metode pembelajaran ini siswa dituntut untuk berpikir cerdas, aktif, kreatif, partisipatif, dan bertanggung jawab. Metode solfegio merupakan suatu bentuk dari praktik belajar, yaitu suatu inovasi pembelajaran yang dirancang untuk membantu siswa memahami teori secara mendalam melalui pengalaman belajar praktik menulis notasi balok.

Praktik belajar ini dapat menjadi program pendidikan yang mendorong kompetensi, tanggung jawab dan partisipasi siswa, belajar menilai dan mempengaruhi kebijakan umum, memberanikan diri untuk berperan serta dalam kegiatan antar siswa, antar sekolah dan antar anggota masyarakat. Uraian di atas sesuai dengan tujuan penelitian yaitu meningkatkan kemampuan menulis notasi balok melalui Metode Solfegio pada siswa kelas VIII- A SMPN 3 Kediri.

\section{KAJIAN TEORITIS}

\section{a. Kemampuan Menulis}

Dalam KBBI (Tim Penyusun, 2005, p.707) kemampuan adalah kesanggupan, kecakapan, atau kekuatan. Sedangkan, Poerwadarminta (2005, p.628) kemampuan adalah suatu kesanggupan atau kecakapan 
untuk melakukan sesuatu dengan baik dan cermat. sedangkan kemampuan menulis permulaan merupakan bekal bagi siswa untuk mempelajari kompetensi dasar yang lain.

\section{b. Pendidikan Seni Musik}

Pelajaran pendidikan seni musik merupakan salah satu mata pelajaran yang diharapkan mampu mengembangkan potensi peserta didik dan juga dapat membentuk kepribadian yang terpuji dari para peserta didik (Wadiyo dalam Herdinasari, 2013, p.35)

\section{c. Notasi Balok}

Titi nada yang dilambangkan dengan tulisan disebut juga notasi musik (Syah, 2014, p.8). Menurut Banoe (2003, p.299) notasi balok adalah tulisan musik dengan lima garis datar, untuk menunjukkan tinggi dan rendahnya nada atau bunyi. Menurut Martinus (2001, p.404) notasi balok adalah tanda tulis yang memiliki titi nada dan tanda nada. Menurut Eko Kurniawan (2011, p. 26) untuk dapat menguasai teori musik, hal yang pertama kali yang harus dikuasai adalah membaca notasi, karena, apabila diibaratkan belajar membaca, maka notasi merupakan gambaran huruf-huruf tertulis yang digunakan untuk membaca. Notasi atau sering disebut dengan not disimbolkan dengan simbol-simbol notasi atau sering disebut not balok.

Sedangkan menurut Trias Radika Herdinasari (2013) notasi musik balok tersusun atas lima garis lurus horizontal yang membentuk sangkar nada. Menurut Maressa, dkk (2013) Untuk dapat membaca not balok, terlebih dahulu harus memahami unsur-unsur dalam not balok yaitu Clef dan tanda kunci.

\section{d. Metode Solfegio}

Metode solfegio adalah istilah yang mengacu pada latihan menyanyi tangga nada, interval, dan latihan melodimelodi dengan syllabus solmisation yaitu, dengan menggunakan suku kata, menyanyi solmisasi dan kemudian dikembangkan dengan menggunakan huruf vokal (AIUEO) sebagai ganti solmisasi atau juga bisa menggunakan huruf atau suku kata lain (Stanley dalam Sumaryanto (2005, p.40).

\section{METODE}

Penelitian tindakan kelas atau PTK yaitu penelitian yang dilakukan oleh guru di kelasnya atau di sekolah dengan penekanan pada penyempurnaan atau peningkatan proses dan praktek pembelajaran. Tujuan PTK adalah untuk memperbaiki dan meningkatkan kualitas praktek pembelajaran secara berkesinambungan sehingga meningkatkan mutu hasil instruksional mengembangkan keterampilan guru, meningkatkan relevansi, meningkatkan efisiensi pengolahan instruksional serta menumbuhkan budaya meneliti pada komunitas guru.

Penelitian tindakan kelas menggambarkan sebagai suatu proses yang dinamis meliputi aspek perencanaan, tindakan, observasi, refleksi yang merupakan langkah berurutan dalam satu siklus atau daur yang berhubungan dengan siklus berikutnya. Adapun jenis tindakan yang diteliti adalah hasil belajar siswa dalam proses belajar mengajar dengan materi menulis not balok.

Desain penelitian yang dirancang terdiri dari : 1) Perencanaan Tindakan, 2) Pelaksanaan Tindakan, 3) Observasi dan Evaluasi dan, 4) Refleksi yang dilakukan selama dua siklus. Subyek dalam penelitian ini adalah siswa kelas VIII-A sejumlah 34 siswa yang terdiri laki-laki: 13 dan perempuan: 21, sekolah ini merupakan dengan predikat Sekolah Standar Nasional yang ada di Kota Kediri.

Sumber data adalah subjek darimana data diperoleh (Arikunto, 2006). Berdasarkan pernyataan tersebut, maka sumber data utama dalam penelitian ini adalah siswa yang mengikuti kegiatan pembelajaran musik karena dalam hal ini siswa merupakan pelaku utama yang menampilkan perubahan yang terjadi setelah tindakan dilakukan. Sumber data lain terletak pada guru beserta staf yang masih bersangkutan.

Data yang digunakan dalam penelitian ini yaitu data kuantitatif berupa tes meningkatkan hasil belajar dengan tes tulis dan data kualitatif digunakanlah instrumen berupa lembar pengamatan observasi terhadap siswa.

Ada empat cara yang mendasar untuk mengumpulkan informasi, yaitu observasi, dokumen, dan materi. Teknik pengumpulan data yang digunakan meliputi observasi, 
dokumentasi dan tes tulis.

Analisis setelah kegiatan di lapangan adalah bagaimana evidensi dan bukti dalam penelitian ini dipresentasikan. Analisis data merupakan usaha memilih, memilah, menggolongkan data untuk menjawab rumusan masalah penelitian yang bertujuan meningkatkan hasil belajar lagu nusantara di SMPN 3 Kediri. Analisis data dalam penelitian ini menggunakan prosentase untuk memenuhi pencapaian nilai siswa yaitu Kriteria Ketuntasan Minimal (KKM) yaitu 75. Data yang akan dianalisis secara deskriptif kualitatif dan deskriptif kuantitatif, data yang diperoleh dari analisis secara kualitatif antara lain: lembar penilaian, serta hasil belajar pengetahuan, hasil tes diambil dari nilai pengetahuan.

Penelitian tindakan kelas ini dilaksanakan secara bersiklus melalui tahapan. Tahapan tersebut dilakukan sebanyak 2 kali, yaitu siklus I meliputi perencanaan, pelaksanaan, tindakan, refleksi. Dari hasil refleksi siklus I, dapat dilaksanakan perancangan ulang pada siklus berikutnya bila dirasa hasilnya belum maksimal. Pengolahan data dalam penelitian ini dilakukan dengan menelaah semua data yang diperoleh melalui observasi aktivitas siswa dan tes.

\section{PEMBAHASAN}

Penelitian ini diterapkan pada Standar Kompetensi 4. mengekspresikan diri melalui karya seni musik. Kompetensi Dasar 4.1 mengaransir secara sederhana lagu etnik Nusantara dalam bentuk ansambel. Indikator: mampu menuliskan lagu nusantara notasi angka dengan lancar.

Sebelum melakukan tindakan, observasi awal yang dilakukan peneliti yaitu dengan mengamati proses pembelajaran pada siswa. Mendiskusikan dengan guru mata pelajaran seni budaya sub bidang seni musik, selama diskusi dengan guru seni budaya sub bidang seni musik, peneliti menyampaikan metode yang digunakan dalam mengajar masih merasa kurang memenuhi harapan dan kurang maksimal dalam pembelajaran, selain menggunakan metode tersebut guru juga hanya menggunakan pujian untuk memberikan dorongan kepada siswa. Dalam setiap pembelajaran guru juga terlihat sangat serius dalam menyampaikan materi pembelajaran sehingga suasana pembelajaran di dalam kelas menjadi tidak menarik bagi siswa, siswa enggan dalam mengikuti pelajaran tersebut sehingga tidak sesuai dengan keinginannya melainkan hanya disebabkan oleh rasa takut dan bukan karena menyukai pelajaran seni budaya sub bidang seni musik.

Persentase ketuntasan belajar siswa hanya sebanyak 6 siswa dengan persentase $17,6 \%$ telah tuntas melebihi nilai KKM (75) sedangkan sebanyak 28 siswa dengan persentase $82,3 \%$ belum mencapai nilai standar ketuntasan belajar. Hasil ini sangat jauh dari harapan maka dari itu harus dilakukan uji ulang dengan melakukan tahapan siklus.

Persentase ketuntasan belajar siswa pada siklus I menunjukkan sebanyak 24 siswa dengan persentase 70,5\% telah tuntas melebihi nilai KKM (75) sedangkan sebanyak 10 siswa dengan persentase 29,5 $\%$ belum mencapai nilai standar ketuntasan belajar. Untuk menghitung nilai rata-rata dalam satu kelas dengan cara jumlah nilai seluruh siswa yaitu 2589 dibagi dengan jumlah keseluruhan siswa yaitu 34 , sehingga diperoleh hasil nilai rata- rata kelas mata pelajaran seni budaya sub seni musik sebesar 76,14 pada siklus I ini menunjukkan bahwa pencapaian nilai sesuai KKM belum sepenuhnya terpenuhi.

Pada siklus II akan melanjutkan materi dari siklus I perbedaannya antara siklus I dan siklus II terletak pada saat pembelajaran siswa memakai identitas no absen, pada siklus II masing masing siswa memiliki tanggung jawab untuk mencermati bentuk not balok sesuai dengan nilai not, penggunaan media kartu not sarana untuk siswa amatlah penting dan membantu sekali dalam proses pembelajaran agar lebih maksimal.

Pada siklus II sudah terlihat kemajuan siswa menerima materi itu dibuktikan dari hasil belajar siswa yang prosentase nilainya semakin meningkat. Guru telah mampu 
untuk mengelola kelas sehingga siswa menjadi lebih nyaman dan dapat menerima materi dengan baik yang disampaikan oleh guru.

Pada siklus ini hampir seluruh siswa sudah mencapai ketuntasan hanya ada 1 siswa yang memiliki nilai dibawah KKM dan ada 33 siswa yang telah mencapai nilai KKM yaitu 75. Hal itu dibuktikan dari prosentase nilai siswa yang mendapatkan nilai lebih dari KKM yaitu (75). Siswa mampu mengikuti pembelajaran materi Menyusun notasi balok dalam bentuk aransir sederhana dari satu lagu Nusantara yang dipresentasikannya, semangat siswa semakin besar untuk mengikuti pelajaran Seni Budaya Sub Seni Musik. Dari data yang diperoleh pada siklus II dapat disimpulkan bahwa kegiatan belajar siswa mengalami peningkatan.

Persentase ketuntasan belajar siswa pada siklus II menunjukkan sebanyak 33 siswa telah tuntas melebihi nilai KKM (75) sedangkan sebanyak 1 siswa belum mencapai nilai standar ketuntasan belajar. Untuk menghitung nilai rata-rata dalam satu kelas dengan cara jumlah nilai seluruh siswa yaitu 2856 dibagi dengan jumlah keseluruhan siswa yaitu 34, total dari pembagian tersebut didapatkan nilai rata-rata kelas yaitu 84 .

Dari pengamatan siklus I dari jumlah siswa 34, sebanyak 10 siswa dengan persentase $29,41 \%$ siswa belum mencapai KKM dalam hal melagukan tangga nada, siswa tidak dapat meletakkan notasi angka sesuai sukat birama / ruas birama, siswa tidak dapat menuliskan notasi lagu dengan ketukannya dan pada siklus II, dari jumlah siswa 34 hanya 1 siswa dengan prosentase 2,94 \% belum mencapai KKM dalam hal mengubah notasi angka ke dalam notasi balok, dan sejumlah 33 anak dengan prosentase $97,05 \%$ telah mencapai KKM. Dengan penambahan media kartu not dan nomor dada metode solfegio dapat meningkatkan kemampuan menulis notasi balok pada siswa Kelas VIII-A SMP Negeri 3 Kediri.

Aspek perkembangan Seni Musik anak SMP memasuki tahap dimana mereka ingin berkreasi dan mengembangkan potensi yang berada dalam bernyanyi lagu nusantara tetapi bermain musik yang dimiliki masingmasing individu satu dengan yang lainnya berbeda-beda. Hal ini ditunjukkan pada peningkatan keterampilan menulis notasi balok siswa kelas VIII - A SMP Negeri 3 Kediri yang dinilai melalui kemampuan menulis notasi siswa itu sendiri, melalui kemampuan menulis notasi balok.

Pada siklus I menunjukkan sebanyak 24 siswa dengan persentase 70,5\% telah tuntas melebihi nilai KKM (75) sedangkan sebanyak 10 siswa dengan persentase 29,5 $\%$ belum mencapai nilai standar ketuntasan belajar. Pada hasil siklus II guru berhasil menerapkan Metode Solfegio lebih maksimal. Hal ini dapat dibuktikan pada siklus II siswa yang mencapai nilai diatas KKM 75 dengan jumlah 34 siswa tuntas dengan prosentase 97,1 \%. Dari hasil tersebut guru Seni Budaya bidang studi Seni Musik sebagai observer membuktikan pada siklus II penerapan Metode Solfegio berhasil meningkatkan kemampuan menulis notasi balok di kelas VIII - A SMP Negeri 3 Kediri.

Peningkatan Hasil belajar siswa dipengaruhi oleh beberapa faktor antara lain: 1) Metode yang diterapkan oleh guru Seni Budaya bidang studi Seni Musik sangat berpengaruh. Penerapan Metode solfegio siswa lebih bersemangat dan bersungguh sungguh dalam mengikuti pembelajaran di kelas 2) Teknik permainan kartu not akan lebih mempercepat proses menghafal dalam susunan nada berbentuk notasi balok. Dengan tujuan agar masingmasing siswa memiliki tanggung jawab untuk menghafal sehingga mampu menulis notasi balok dengan baik dan mampu untuk menyalin not angka ke dalam not balok lagu nusantara. 3) Penambahan teknik permainan kartu not. Hal ini untuk membuat siswa lebih kreatif. Dengan tujuan siswa mampu membuka wawasan agar lebih kreatif dan inovatif dalam meramu sebuah musik secara kelompok. 4) Pembentukan kelompok kecil sehingga mendorong siswa untuk aktif belajar dalam kelas dengan sistem siswa yang aktif dan siswa yang pasif di acak agar semua rata. Dengan tujuan kerjasama antara siswa satu dengan yang lain. 


\section{KESIMPULAN DAN SARAN \\ a. Kesimpulan}

Berdasarkan hasil dari analisis data dan hasil dari penelitian dalam bab terdahulu, dapat disimpulkan bahwa setiap metode yang dipilih akan mempengaruhi keterampilan dan hasil belajar siswa dalam pembelajaran Seni Budaya Sub Seni Musik. Tinggi rendahnya keterampilan belajar tersebut nantinya akan mempengaruhi peningkatan hasil belajar siswa secara individu. Peningkatan keterampilan menulis not balok dengan penerapan Metode Solfegio kelas VIII - A SMP Negeri 3 Kediri dapat diuraikan sebagai berikut:

\section{1) Siklus I}

Penerapan Metode solfegio pada siklus ini belum terlalu efektif untuk meningkatkan keterampilan siswa dalam menulis notasi balok. Pada siklus I siswa yang mendapatkan nilai $91-100$ sejumlah 1 siswa dengan persentase $2,9 \%$, siswa yang mendapatkan nilai 81 - 90 sejumlah 5 siswa dengan persentase $11,7 \%$, siswa yang mendapat nilai 71 80 sejumlah 22 siswa dengan persentase $64.7 \%$, siswa yang mendapat nilai $\leq 70$ sejumlah 6 siswa dengan prosentase 17,5\%. Pada siklus I sebagian besar belum mencapai ketuntasan yang diharapkan. Hal tersebut dapat disimpulkan hasil belajar siswa yang sebagian belum mencapai standar ketuntasan minimum.

\section{2) Siklus II}

Penerapan Metode solfegio pada siklus II mampu untuk meningkatkan hasil belajar menulis notasi balok. Pada siklus II siswa yang mendapatkan nilai 91 - 100 sejumlah 3 siswa dengan persentase $8,8 \%$, siswa yang mendapatkan nilai $81-90$ sejumlah 22 siswa dengan persentase $64,7 \%$, siswa yang mendapat nilai $71-80$ sejumlah 8 siswa dengan persentase $23,5 \%$, dan satu orang siswa saja yang mendapat nilai $\leq$ 70 dengan persentase 2,9\% Dengan demikian, Metode Solfegio dapat meningkatkan kualitas hasil belajar menulis notasi balok. Hal tersebut ditunjukkan dengan adanya peningkatan hasil ketuntasan belajar siswa dalam menulis notasi balok.

\section{b. Saran}

Berdasarkan dari hasil penelitian yang telah dilakukan, peneliti memberikan saran sebagai berikut : bagi Guru Seni Budaya di SMP Negeri 3 Kediri, dapat dipertimbangkan opsi pengajaran menggunakan metode solfegio sebagai referensi untuk meningkatkan kualitas hasil belajar membaca notasi balok dalam bidang studi Seni Musik. Bagi siswa, disarankan metode solfegio tersebut dapat meningkatkan semangat dan motivasi belajar siswa, sehingga siswa aktif dan responsif dalam pembelajaran Seni Budaya bidang studi Seni Musik. Sehubungan dengan itu, siswa juga diharapkan dapat memberikan hasil belajar yang maksimal. Bagi mahasiswa pendidikan Seni Tari dan Musik, disarankan agar penelitian ini dapat menjadi bahan masukan tentang Penelitian Tindakan Kelas dalam penyelesaian tugas akhir pada bidang dan aspek yang bersangkutan. Terakhir, diharapkan juga bagi Universitas Negeri Malang agar dapat menggunakan penelitian ini sebagai bahan referensi tentang pemilihan Metode Pembelajaran yang tepat sesuai dengan Kompetensi Dasar yang dipakai.

\section{DAFTAR RUJUKAN}

Arikunto Suharsimi, Suhardjono, dan Supardi. 2010. Penelitian Tindakan Kelas. Jakarta: Bumi Aksara.

Adi, Tirto. 2007. Inovasi Pembelajaran, Media Pendidikan. Surabaya: Kanwil P dan K Jawa Timur.

Herdinasari, Trias Radika dan Sumaryanto, Totok. 2013. Upaya Meningkatkan Minat dan Hasil Belajar Membaca Notasi Musik Balok melalui Media Pembelajaran Sibelius pada Siswa Kelas VII G SMP Negeri 4 Ungaran. Jurnal Seni Musik. ISSN 2301-4091. Jurusan Sendratasik FBS Universitas Negeri Semarang Indonesia.

Kurniawan, Eko. 2011. 100\% Pasti Jago Bermain Keyboard. Yogyakarta: Buku Biru.

Maressa, Tri Chintia., Toruan, Jagar Lumbang., Yuliasma. 2013. Peningkatan Hasil Belajar Siswa Membaca Notasi Balok menggunakan Alat Musik di SMPN 4 Pariaman.E-Jurnal Vol.2 No.12013 Seri B. 
Jurusan Sendratasik FBS Universitas Negeri Padang.

Martinus, Surawan. 2001. Kamus Kata Serapan. Jakarta: Gramedia Pustaka.

Poerwadarminta. 2005. Kamus Besar Bahasa Indonesia. Jakarta: Balai Pustaka.

Puspita, P. S. (2016). Problematika Guru Non Pendidikan Musik Dalam Penyampaian Materi Pembelajaran Musik di SMP Negeri Se-Kabupaten Magelang. Universitas Negeri Yogyakarta.

Sumaryanto, Totok. 2005. Efektivitas Penggunaan Metode Solfegio untuk Pembelajaran Keterampilan Bermain Musik di Sekolah Dasar. Harmonia: Journal of Arts Research and Education. ISSN 2302-3201 Vol.7 No.1 Seri A September 2018. Universitas Negeri Semarang Indonesia.

Syah, Priawan Dwi Arifin. 2014. Upaya Meningkatkan Kemampuan Membaca Notasi Balok dengan Menggunakan Media Sibelius 6 di SMP Negeri 12 Yogyakarta. Skripsi: Jurusan Pendidikan Seni Musik FBS Universitas Negeri Yogyakarta.

Tim Penyusun. 2005. Kamus Besar Bahasa Indonesia Edisi Tiga. Jakarta: Balai Pustaka. 